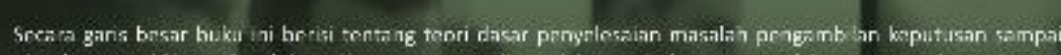

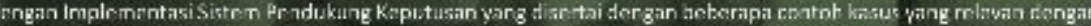

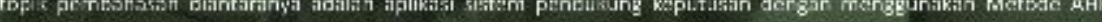

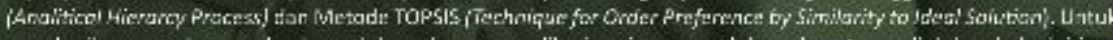

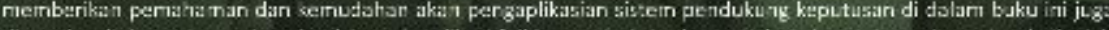

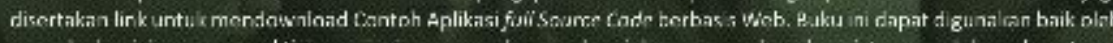

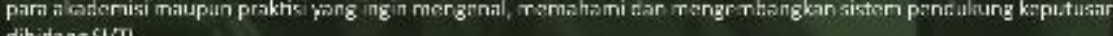
dibitang SI/TI.

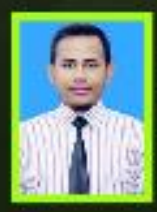

Sofiansysh Fadli, S.Kom., M.Kom, lahir padu 29 Juli 1990 di Kota Girna, Kuss Tersyare

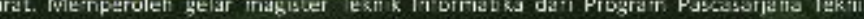

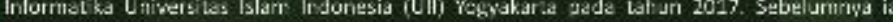

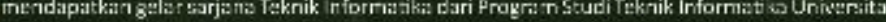

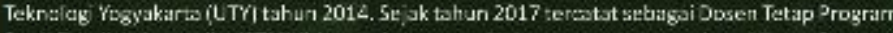

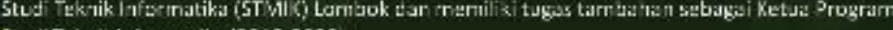
Studi Tekri infrifornstika (2019-2020).

Sala n tu, la juia menzajar oi UNu vTB IUniversitas Nahclatul Ulama Nisa Tenfara Barati. Ocsen denzampt

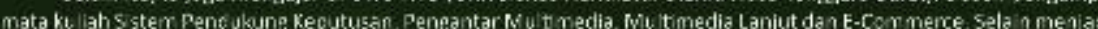

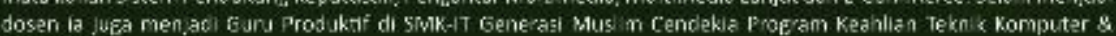
Jaringan.

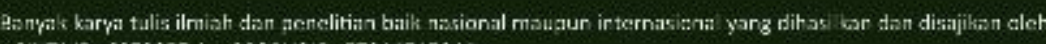

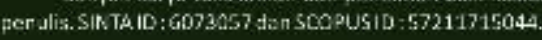

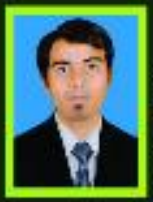

Khairul Imthan, 5.Kom, M. Kam lahir di Kelazu 26 Seatenter 1987, Perd dika I Sarja na

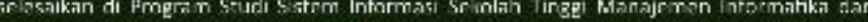

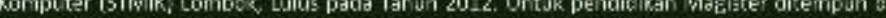

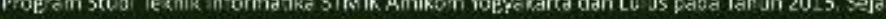

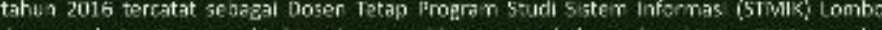

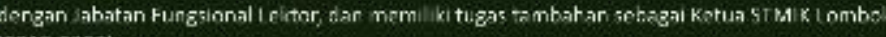
12018-2020:

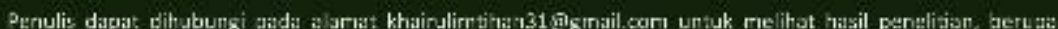

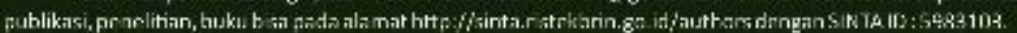

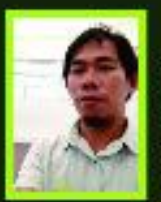

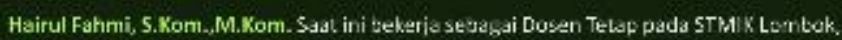

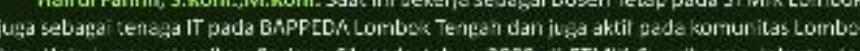

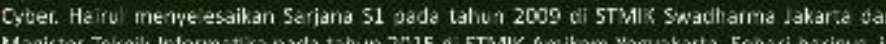

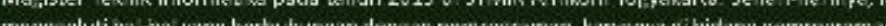

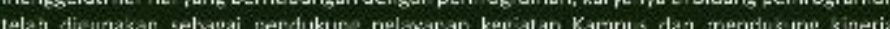

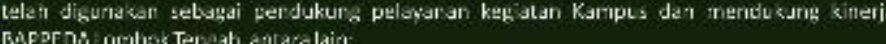

1. AplikasislakadSTM K Lambol

AplikasiSI:GTASTMA K Lombok

Aplikasit-monev 17 koern BAPPCD:

AplikasisSHGMPPEC?

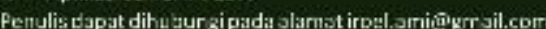
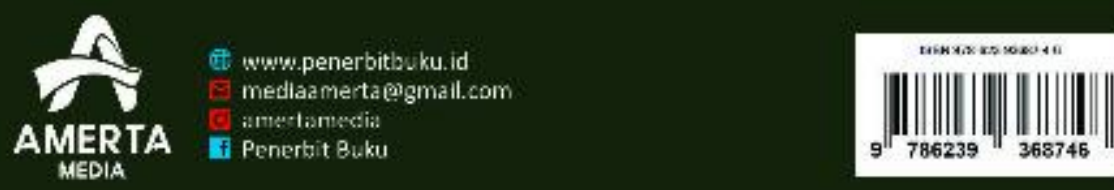

疍

Pendekatan Praktis :

Dilengkapi dengan Contoh Kasus,

Implementasi \& Aplikasi Evaluasi Kinerja

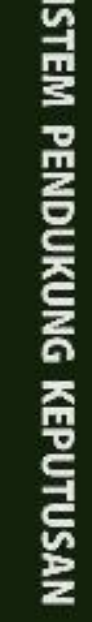

\section{MENGENALDAN MEMAHAMI
SISIEN DENDIUTUNG \\ MENCENAL DANMENAAAMI
SISTEM PENDUKUNG KEPUTUSAN}

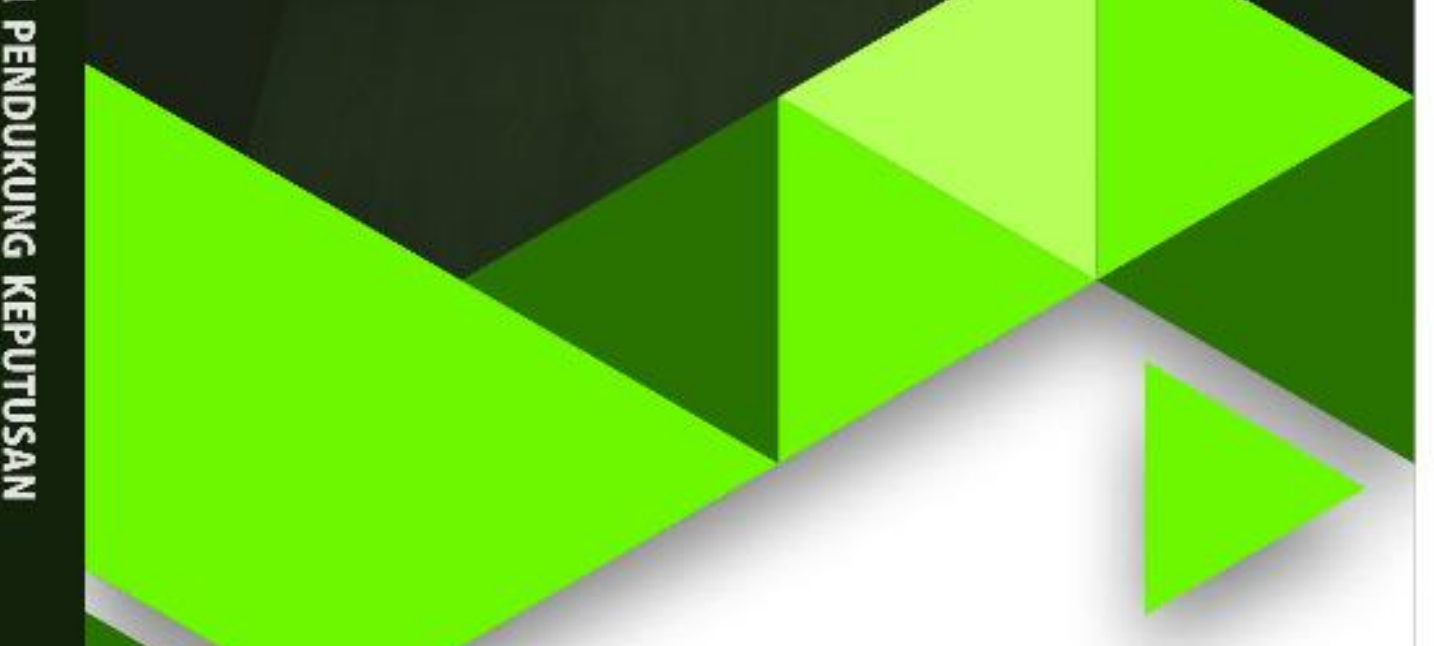

$\frac{R}{8}$

Soflansyah Fadli, S.Kom., M.Kom Khairul Imtihan, S.Kom.,M.Kom Hairul Fahmi, S.Kom.,M.Kom 


\section{MENGENAL DAN MEMAHAMI SISTEM PENDUKUNG KEPUTUSAN}




\title{
MENGENAL DAN MEMAHAMI SISTEM PENDUKUNG KEPUTUSAN
}

\author{
Copyright@ 2020
}

Sofiansyah Fadli, S.Kom,. M.Kom Khairul Imtihan, S.Kom,. M.Kom

Hairul Fahmi, S.Kom,. M.Kom

Diterbitkan pertama kali oleh CV Amerta Media

Hak cipta dilindungi oleh undang-undang All Rights Reserved

Hak penerbitan pada Penerbit Amerta Media

Dilarang mengutip atau memperbayak sebagian atau seluruh isi buku ini tanpa seizin tertulis dari Penerbit

\section{Anggota IKAPI}

Cetakan Pertama: Mei 2020

$15 \mathrm{~cm} \times 23 \mathrm{~cm}$

ISBN: 978-9239-3687-4-6

Penulis : Sofiansyah Fadli, S.Kom,. M.Kom Khairul Imtihan, S.Kom,. M.Kom Hairul Fahmi, S.Kom,. M.Kom

Editor : Aan Herdiana, M.Sos Tegar Roli A., M.Sos

Desain Cover : Adji Azizurrachman

Tata Letak : Dendy Taufiqa Candra

\section{Diterbitkan Oleh :}

CV. Amerta Media

NIB. 0220002381476

NP. 202003-1708-4520-1345-639

Email : mediaamerta@gmail.com Website: www.penerbitbuku.id Whatsapp : 081-356-3333-24

Perpustakaan Nasional: Katalog dalam Terbitan (KdT) MENGENAL DAN MEMAHAMI SISTEM PENDUKUNG KEPUTUSAN

dengan Pendekatan Experiential Marketing Sofiansyah Fadli, S.Kom,. M.Kom

Khairul Imtihan, S.Kom,. M.Kom

Hairul Fahmi, S.Kom,. M.Kom

Cet.1 - Penerbit Amerta Media, M 


\section{DAFTAR ISI}

BAB 1

PENDAHULUAN

BAB 2

PENILAIAN KINERJA

BAB 3

KEPALA SEKOLAH

BAB 4

SISTEM PENDUKUNG KEPUTUSAN

BAB 525

Konsep Dasar Multi-Attribut Decision Making (MADM)

BAB 6

METODE PENELITIAN

BAB 7

DESKRIPSI IMPLEMENTASI SISTEM

PENDUKUNG KEPUTUSAN EVALUASI

KINERJA KEPALA SEKOLAH

BAB 8

PENUTUP

DAFTAR PUSTAKA

TENTANG PENULIS 



\section{KATA PENGANTAR}

Bismillahirrohmanirrohim. Alhamdulillah dengan rasa syukur kehadirat Allah SWT atas segala limpahan rahmat, hidayah dan karunia-Nya sehingga dapat diselesaikannya buku yang berjudul "Mengenal dan Memahami Sistem Pendukung Keputusan". Dalam penyelesaian buku ini, penulis banyak mendapatkan bantuan dari berbagai pihak. Untuk itu, ungkapan rasa terima kasih yang sebesar-besarnya disampaikan kepada semua pihak yang telah memberikan dukungan moril maupun materil secara langsung maupun tidak langsung kepada penulis. Selain buku ini bisa digunakan sebagai buku pegangan bagi para pengajar, buku ini disusun agar dapat membantu para mahasiswa, dosen ataupun peneliti dalam mengenal dan memahami serta memberikan kemudahan dalam mempelajari sistem pendukung keputusan terutama bagi kaum awam yang belum mengenal sistem pendukung keputusan itu sendiri. Pemaparan buku sistem pendukung keputusan ini dimulai dari teori dasar sampai dengan implementasinya. Contoh aplikasi yang berisi full source code program berbasis WEB dapat diunduh melalui Link https://bit. ly/aplikasispk1dan https://bit.ly/aplikasispk2 tentunya dengan terlebih dahulu harus memiliki buku ini. 
Penulis menyadari jika di dalam penyusunan buku ini mempunyai kekurangan, namun penulis meyakini sepenuhnya bahwa sekecil apapun buku ini tetap akan memberikan sebuah manfaat bagi pembaca. Akhir kata untuk penyempurnaan buku ini, maka kritik dan saran yang bersifat membangun dari pembaca sangatlah berguna untuk penulis kedepannya.

Praya, 11 Mei 2020

Penulis 


\section{BAB 1 \\ PENDAHULUAN}

\section{Latar Belakang}

Pemerintah telah mengeluarkan kebijakan terkait dengan penilaian kinerja pendidik dan tenaga kependidikan yang merupakan salah satu strategi dalam melakukan pembinaan dan pengawasan untuk menjaga profesionalitas dalam melaksanakan tugasnya, pembinaan karir, peningkatan kompetensi, penjaminan mutu dan pemberian tunjangan profesi kepala sekolah. Penilaian kinerja pendidik dan tenaga kependidikan ini salah satu diantaranya adalah penilaian kinerja kepala sekolah/madrasah. Dalam pelaksanaan penilaian kinerja kepala sekolah fokus utamanya adalah bagaimana meningkatkan kemampuan profesional kepala sekolah/madrasah secara terencana melalui proses perbaikan mutu secara berkelanjutan. Sehingga perkembangan mutu perlu dipetakan secara berkala agar terwujud profil kepala sekolah berbasis data hasil pengukuran.

Permendiknas No. 13 Tahun 2007 tentang Standar Kepala Sekolah/Madrasah dan Permendiknas No. 28 Tahun 2010 Penugasan guru sebagai Kepala Sekolah/Madrasah, Pasal 12 
menyatakan bahwa: (1) Penilaian kinerja kepala sekolah/ madrasah dilakukan secara berkala setiap tahun dan secara kumulatif setiap empat tahun; (2) Penilaian kinerja tahunan dilaksanakan oleh pengawas sekolah/madrasah; (3) Penilaian kinerja empat tahunan dilaksanakan oleh atasan langsung dengan mempertimbangkan penilaian kinerja oleh tim penilai dari pengawas sekolah/madrasah, pendidik, tenaga kependidikan, dan komite sekolah/madrasah dari tempatnya bertugas; (4) Hasil penilaian kinerja dikategorikan dalam tingkatan amat baik, baik, cukup, sedang atau kurang.

Kepala sekolah adalah pemimpin tertinggi sebuah lembaga pendidikan formal yang bertanggung jawab terhadap kegiatan belajar mengajar, serta mengembangkan potensi yang ada di lembaga tersebut serta memiliki posisi strategis dalam rangka menumbuh kembangkan kedisiplinan guru dan kinerja guru yang ada dalam sekolah itu sendiri. Dalam perannya sebagai seorang pendidik, kepala sekolah harus menanamkan, memajukan, dan meningkatkan nilai mental dan moral kepada guru atau tenaga fungsional yang lainnya, tenaga administrasi (staf) dan para peserta didik (Mulyasa, 2006).

Penilaian kinerja kepala sekolah dilakukan oleh pengawas sekolah untuk, menunjang efektivitas pelaksanaan penilaian diperlukan pedoman sebagai acuan dalam pelaksanaan penilaian kinerja kepala sekolah/madrasah dan acuan dalam tindaklanjut pengelolaan data. Pedoman evaluasi kinerja kepala sekolah ini mengacu pada Peraturan Menteri Pendidikan Nasional Nomor 13 Tahun 2007 tentang Standar Kepala Sekolah/Madrasah dan Peraturan Menteri Pendidikan Nasional Nomor 35 Tahun 2010 
tentang Petunjuk Teknis Pelaksanaan Jabatan Fungsional Guru dan Angka Kreditnya bahwa Kepala Sekolah mempunyai 6 (enam) kriteria kompetensi yang dijadikan penilaian kinerja kepala sekolah. 6 (enam) kompetensi tersebut antara lain: 1) kepribadian dan sosial; 2) kepemimpinan pembelajaran; 3) pengembangan sekolah; 4) manajemen sumber daya; 5) kewirausahaan; 6) supervisi pembelajaran yang menjadi tolak ukur untuk mengevaluasi kinerja kepala sekolah.

Menurut Kemendikbud Badan PSDMPK-PMP/ PUSBANGTENDIK (2012), masalah yang akan timbul ketika evaluasi penilaian kinerja kepala sekolah tidak dilakukan antara lain: program pembinaan kepala sekolah belum terintegrasi secara sistemik, perencanaan, pelaksanaan dan evaluasi program pengelolan sekolah belum terlaksana dengan efektif, penurunan kinerja, citra dan wibawa kepala sekolah khususnya kepala sekolah di pemerintah daerah Kabupaten Lombok Tengah, penguasaan standar kompetensi kepala sekolah belum merata.

Pada umumnya skema manajemen kinerja disusun dengan menggunakan peringkat dan ditetapkan setelah dilaksanakan penilaian kinerja. Peringkat menunjukkan kualitas kinerja atau kompetensi yang ditampilkan pegawai dengan memilih tingkat pada skala yang paling dekat dengan pandangan penilai tentang seberapa baik kinerja pegawai (Armstrong \& Taylor, 2009). Lebih lanjut lagi (Rivai, 2009) menyatakan bahwa penilaian kinerja mengacu pada suatu sistem formal dan terstruktur yang digunakan untuk mengukur, menilai, dan mempengaruhi sifatsifat yang berkaitan dengan pekerjaan, perilaku, dan hasil, termasuk tingkat ketidakhadiran. Pengukuran kinerja merupakan 
komponen sistem strategis dalam penerapan standar karena dapat mengukur efektivitas peningkatan mutu proses dan akuntabilitas institusi (Sallis, 2002).

Penilaian kinerja kepala sekolah/madrasah dilaksanakan oleh pengawas yang ditunjuk oleh kepala dinas kabupaten/kota sesuai dengan kewenangannya. Penilaian dilakukan dengan cara memberikan skor pada setiap kriteria berdasarkan kelengkapan dan keabsahan bukti yang relevan. Dalam penilaian kinerja kepala sekolah diukur berdasarkan enam komponen kriteria seperti: kepribadian dan sosial, kepemimpinan pembelajaran, pengembangan sekolah, manajemen sumber daya, kewirausahaan dan supervisi pembelajaran, dimana tiap komponen kriteria mempunyai subkriteria masing-masing dan tiap subkriteria mempunyai point-point penilaian masing-masing menggunakan skala 1 sampai 4 dengan masing-masing skala menyatakan; amat baik, baik, cukup dan kurang.

Bukti-bukti dapat berupa data, dokumen, kondisi lingkungan fisik sekolah/madrasah, perilaku dan budaya yang dapat diidentifikasi oleh penilai melalui pengkajian, pengamatan dan penggalian informasi dari pihak yang terkait disekolah/ madrasah seperti guru, pegawai, komite sekolah/madrasah. Pemberian skor harus didasarkan kepada catatan hasil pengkajian serta bukti-bukti lain yang dikumpulkan selama proses penilaian kinerja kepala sekolah/madrasah, dokumen hasil dari penilaian kinerja tidak dipaparkan sehingga kepala sekolah tidak mengetahui hasil dari penilaian kinerja tersebut. Hal ini tidak sejalan dengan prinsip penilaian kinerja kepala sekolah sesuai dengan Permendiknas Nomor 20 Tahun 2007 Tentang Standar 
Penilaian sebagai berikut: (1) Objektif, penilaian berdasarkan pada prosedur dan kriteria yang jelas. (2) Adil, penilaian tidak menguntungkan atau merugikan kepala sekolah/madrasah karena perbedaan latar belakang agama, suku, budaya, adat istiadat, dan gender. (3) Terbuka, prosedur penilaian, kriteria penilaian dan dasar pengambilan keputusan dapat diketahui oleh pihak-pihak yang berkepentingan.

Dalam pelaksanaan sampai sekarang pemerintah daerah selama ini khususnya Kabupaten Lombok Tengah, berdasarkan penjelasan dari koordinator pengawas (korwas) Kabuapten Lombok Tengah bahwa penilaian evaluasi kinerja kepala sekolah dilaksanakansecarakonvensionalsehinggamenimbulkanbeberapa masalah yang terjadi, diantaranya adalah masih menggunakan sistem manual (tidak efisiensi dalam penggunaan anggaran, karena setiap melakukan penilaian kinerja selalu melakukan pengadaan dan penggandaan instrument), membutuhkan waktu yang cukup lama (diolah berdasarkan perhitungan manual), tidak ditentukan kriteria dan subkriteria mana yang menjadi elemen penting yang harus mendapatkan perhatian kepala sekolah dalam rangka meningkatkan kinerja, kepala sekolah tidak mengetahui hasil evaluasi kinerja pada kompetensi mana yang unggul dan kompetensi yang kurang, adanya subyektifitas dalam pengambilan keputusan, misalkan jika beberapa kepala sekolah yang ada memiliki kemampuan yang tidak jauh berbeda. Sehingga mutasi kepala sekolah, promosi kepala sekolah dan pemberhentian kepala sekolah merupakan kebijakan dan kewenangan bupati sebagai kepala daerah, akibatnya banyak kepala sekolah yang tidak memiliki kompetensi yang tidak bagus/layak dalam memipin 
sekolah, karena tidak atas dasar penilaian evaluasi kinerja kepala sekolah. Hal tersebut dapat menimbulkan masalah seperti pengelolaan sekolah yg tidak transparan, penjaminan mutu yang tidak terlaksana, kepemimpinan pembelajaran yang tidak efektif, pengembangan sekolah yang tidak terarah (karena kepala sekolah tidak berkompetensi), penurunan kinerja kepala sekolah (Tohar, 2015).

Jika proses pengambilan keputusan ini dibantu oleh sebuah sistem pendukung keputusan yang terkomputerisasi diharapkan subjektvitas dalam pengambilan keputusan dapat diminimalisir dan dapat melaksanakan serta menerapkan seluruh kriteriakriteria kompetensi untuk seluruh kepala sekolah. Sehingga hasil yang didapatkan akan bisa menentukan pembinaan yang akan dilakukan untuk meningkatkan kualitas kinerja kepala sekolah.

Dalam penelitian yang dilakukan oleh (Mufizar dkk, 2015) menyimpulkan bahwa telah berhasil dibangun sistem pendukung keputusan penilaian kinerja guru dengan menggunakan metode analitycal hierrarchy process untuk menghasilkan keputusan berupa penilaian kinerja guru, sistem pendukung keputusan ini dibangun dengan melakukan penambahan kriteria-kriteria sehingga mampu mengurangi tingkat subjektifitas dan berdampak pada hasil penilaian kinerja guru menjadi lebih akurat dan tepat.

Dari penjabaran di atas, hal yang menjadi latar belakang masalah ini adalah bagaimanakah sistem pendukung keputusan dapat digunakan sebagai alat bantu untuk mengevaluasi kinerja kepala sekolah, sehingga diharapkan dapat membantu pihak pengambil kebijakan dapat melakukan pengambilan keputusan, untuk mendapatkan informasi yang sahih, objektif dan handal 
tentang kinerja kepala sekolah berdasarkan standar kompetensi kepala sekolah sesuai dengan peraturan yang berlaku, hasil yang didapat digunakan untuk menentukan pembinaan yang akan dilakukan untuk meningkatkan kualitas kinerja kepala sekolah. Metode Ahp dan Topsis digunakan tidak hanya untuk penilaian kinerja semata, tetapi juga digunakan dalam rangka promosi jabatan misalanya ketika akan memberi jabatan hanya dibutuhkan satu orang kepala sekolah, tetapi banyak kepala sekolah yang memenuhi, pemberian penghargaan, memindahkan kepala sekolah tersebut ke sekolah yang lebih baik dan sebaliknya.

\section{Rumusan Masalah}

Berdasarkan latar belakang yang telah dikemukakan maka permasalahan yang diangkat dalam penelitian ini adalah bagaimanakah model sistem pendukung keputusan membantu mengevaluasi kinerja Kepala Sekolah SMA/SMK Negeri SeKabupaten Lombok Tengah Nusa Tenggara Barat.

\section{Tujuan Penelitian}

Dengan mengacu pada perumusan masalah, maka tujuan penelitian ini adalah membuat sistem pendukung keputusan evalusi kinerja kepala sekolah SMA/SMK Se-Kabupaten Lombok Tengah Nusa Tenggara Barat, sebagai solusi menjawab permasalahan yang dideskripsikan pada latar belakang. 


\section{Manfaat Penelitian}

Manfaat penelitian ini diharapkan:

a. Dapat memberikan informasi akurat kepada pihak yang terkait tentang kualitas kinerja kepala sekolah berdasar standar kompetensi.

b. Sebagai dasar penentuan perpanjangan pemberian tugas tambahan sebagai kepala sekolah

c. Sebagai dasar penentuan promosi ke jabatan-jabatan yang terkait dengan tugas-tugas kependidikan

d. Sebagai dasar penentuan angka kredit jabatan guru yang mendapatkan tugas tambahan sebagai kepala sekolah.

\section{Tinjauan Pustaka}

Sebuah penilaian kinerja harus didasari dengan pemilihan kriteria penilaian yang tepat serta adanya penentuan nilai standar dari masing-masing kriteria tersebut. Selain itu kepala sekolah sebagai pihak yang dinilai seharusnya dapat menegetahui kriteria apa saja yang digunakan dalam melakukan penilaian kinerja agar penilaian kinerja dapat dipandang menjadi lebih objektif bagi pihak yang akan dinilai. Dalam kajian pustaka ini memuat beberapa penelitian yang relevan dan dapat dijadikan acuan bagi penulis dalam menyusun penelitian ini. Berikut beberapa penelitian yang dijadikan acuan bagi penulis.

Penelitian yang dilakukan oleh (Wolo dkk, 2011), pengambilan keputusan penilaian kinerja dosen menggunakan metode AHP dapat diketahui bahwa untuk karakteristik dengan tingkat keaktifan dalam menjalankan kegiatan Tridharma 
Perguruan Tinggi, maka nilai rasio consistency lebih kecil. Metode Analitycal Hierrarchy Process(AHP) dapat digunakan untuk pengambilan keputusan penilaian kinerja dosen dengan beberapa kriterianya serta dapat dipakai untuk menganalisa dan menentukan solusi sistem pendukung keputusan untuk penilaian kinerja dosen di Universitas Nusa Nipa Maumere.

Penelitian yang dilakukan oleh (Mufizar dkk, 2015), menyimpulkan telah berhasil dibangun sistem pendukung keputusan penilaian kinerja guru dengan menggunakan metode $A H P$ untuk menghasilkan keputusan berupa penilaian kinerja guru, sistem pendukung keputusan ini dibangun dengan melakukan penambahan kriteria-kriteria sehingga mampu mengurangi tingkat subjektifitas dan berdampak pada hasil penilaian kinerja guru menjadi lebih akurat dan tepat.

Penelitian yang dilakukan oleh (Kusrini \& Gole, 2007), penelitian ini membangun sebuah sistem pendukung keputusan untuk menilai prestasi kerja karyawan dengan menggunakan model Analitycal Hierrarchy Process. Dalam proses penentuan prestasi pegawai, digunakan banyak kriteria (multi kriteria). Dalam aplikasi ini, pengguna diijinkan untuk menentukan kriteria apa saja yang dipakai beserta bobot dari kriteria-kriteria tersebut. Dengan perpaduan antara data kriteria serta bobot yang dimasukkan pengguna dengan data pegawai yang telah ada di perusahaan, aplikasi akan mampu menghasilkan urutan pegawai berprestasi.

Penelitian yang dilakukan oleh (Kusumadewi, 2004), menggunakan Fuzzy quantification theory I untuk menganalisa dan menentukan besarnya faktor yang diberikan secara kualitatif 
hubungan antara penilaian kinerja dosen oleh mahasiswa dengan jumlah kehadiran dosen terhadap nilai kelulusan mahasiswa.

Penelitian yang dilakukan oleh (Kusrini, 2007), sistem pendukung keputusan untuk mengevaluasi kinerja dosen yang mengacu pada aktifitas dosen dalam proses perkuliahan. Hasilnya adalah sebuah rancangan basis data baik data internala maupun data private, rancangan interface berikut prosedur peyimpanan dan pengambilan data.

Penelitian yang dilakukan oleh (Kurniawan \& Kusrini, 2016), mengatakan bahwa sistem yang telah dibuat dapat digunakan untuk menyelesaikan pengambilan keputusan dengan beberapa kriteria-kriteria yang akan menjadi bahan pertimbangan menggunakan Simple Additive Weighting (SAW) untuk mendapakan alternatif keputusan dan menentukan rangking kinerja pegawai dengan nilai tertinggi.

Perbedaan dengan penelitian terdahulu, penelitian ini akan membangun suatu aplikasi sistem pendukung keputusan evaluasi penilaian kinerja kepala sekolah SMA/SMK Negeri SeKabupaten Lombok Tengah Nusa Tenggara Barat yang mengacu pada Permendiknas Nomor 35 Tahun 2010 Tentang Tentang Petunjuk Teknis Pelaksanaan Jabatan Fungsional Guru Dan Angka Kreditrnya. dengan menggunakan Metode AHP dan TOPSIS. AHP dan TOPSIS digunakan karena metode ini dapat membantu pengambil keputusan dalam melakukan pengambilan keputusan terhadap beberapa alternatif keputusan yang harus diambil dengan beberapa kriteria yang akan menjadi bahan pertimbangan untuk mendapatkan suatu keputusan yang sahih dan objektif. Selain itu juga evaluasi kinerja kepala sekolah ini juga dapat menentukan perangkingan dari hasil akumulasi penilaian secara menyeluruh. 


\section{BAB 2 \\ PENILAIAN KINERJA}

\section{Pengertian Kinerja}

Menurut Sulistiyani \& Rosidah (2003), kinerja seseorang merupakan kombinasi dari kemampuan, usaha, dan kesempatan yang dapat dinilai dari hasil kerjanya. Sedangkan menurut Bernardin dan Russel dalam (Sulistiyani \& Rosidah, 2003) menyatakan bahwa, kinerja merupakan catatan outcome yang dihasilkan dari fungsi pegawai tertentu atau kegiatan yang dilakukan selama periode waktu tertentu. Sementara itu, Mangkunegara (2001), menyatakan kinerja (prestasi kerja) adalah hasil kerja secara kualitas dan kuantitas yang dicapai oleh seorang pegawai dalam melaksanakan tugasnya sesuai dengan tanggung jawab yang diberikan kepadanya.

Menurut Kemendikbud Badan PSDMPK-PMP/ PUSBANGTENDIK (2012) penilaian kinerja kepala sekolah/ madrasah merupakan proses pengumpulan, pengolahan, analisis, dan interpretasi data yang sesungguhnya kepala sekolah/ madrasah kerjakan pada setiap indikator pemenuhan standar. Berdasarkan pengertian tersebut yang dimaksud dengan kinerja kepala sekolah/madrasah adalah hasil kerja yang dicapai kepala 
sekolah/madrasah dalam melaksanakan tugas pokok, fungsi dan tanggungjawabnya dalam me-ngelola sekolah yang dipimpinnya.

\section{Pengertian Penilaian Kinerja}

Peraturan Menteri Pendidikan Nasional Nomor 35 Tahun 2010 menjelaskan bahwa penilaian kinerja guru merupakan penilaian tiap butir kegiatan tugas utama guru dalam rangka pembinaan karir kepangkatan dan jabatan. Guru yang dimaksud dalam permendiknas tersebut termasuk guru termasuk guru yang memiliki tugas tambahan sebagai kepala sekolah/madrasah. Peraturan Menteri Pendidikan Nasional Nomor 35 Tahun 2010 menjelaskan bahwa penilaian kinerja guru yang memiliki tugas tambahan sebagai kepala sekolah/madrasah meliputi enam komponen penilaian, yaitu kepribadian dan sosial, kepemimpinan pembelajaran, pengembangan sekolah/madrasah, manajemen sumber daya, kewirausahaan, dan supervisi pembelajaran. Pengertian penilaian kinerja menurut Mangkunegara (2001), bahwa penilaian kinerja (prestasi pegawai) adalah suatu proses penilaian prestasi kerja pegawai yang dilakukan oleh pemimpin perusahaan secara sistematik berdasarkan pekerjaan yang ditugaskan kepadanya.

Menurut Armstrong \& Taylor, (2009)menyatakan bahwa, pumumnya skema manajemen kinerja disusun dengan menggunakan peringkat dan ditetapkan setelah dilaksanakan penilaiann kinerja. Peringkat tersebut menunjukkan kualitas kinerja atau kompetensi yang ditampilkan pegawai dengan memilih tingkat pada skala yang paling dekat dengan pandangan penilai tentang seberapa baik kinerja pegawai. Lebih lanjut lagi 
(Rivai, 2009) menyatakan bahwa, penilaian kinerja mengacu pada suatu sistem formal dan terstruktur yang digunakan untuk mengukur, menilai, yang berkaitan dengan pekerjaan, perilaku, dan hasil, termasuk tingkat ketidakhadiran. Pengukuran kinerja merupakan komponen sistem strategis dalam penerapan standar karena dapat mengukur efektivitas peningkatan mutu proses dan akuntabilitas institusi (Sallis, 2002).[] 